\title{
Guidelines
}

HORMONE

RESEARCH IN

Horm Res Paediatr 2019;91:357-372

PAEDIATRICS

DOI: 10.1159/000501336

Received: February 25, 2019

Accepted: June 4, 2019

Published online: July 18, 2019

\section{Use of Gonadotropin-Releasing Hormone Analogs in Children: Update by an International Consortium}

\author{
Kanthi Bangalore Krishna ${ }^{a}$ John S. Fuquab Alan D. Rogolc Karen O. Klein ${ }^{d}$ \\ Jadranka Popovic ${ }^{e}$ Christopher P. Houk ${ }^{f}$ Evangelia Charmandarig Peter A. Lee ${ }^{a}$ \\ ${ }^{a}$ Division of Pediatric Endocrinology and Diabetes, Department of Pediatrics, Penn State Hershey Medical Center,

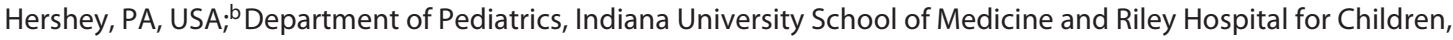 \\ Indianapolis, IN, USA; ' $D$ epartment of Pediatrics, University of Virginia, Charlottesville, VA, USA; dUniversity of \\ California, San Diego and Rady Children's Hospital, San Diego, CA, USA; 'Division of Pediatric Endocrinology, \\ Pediatric Alliance, Pittsburgh, PA, USA; ${ }^{f}$ Department of Pediatrics, Medical College of Georgia, Augusta University, \\ Augusta, GA, USA; ${ }^{9}$ Division of Endocrinology, Metabolism and Diabetes, First Department of Pediatrics, National and \\ Kapodistrian University of Athens Medical School, "Aghia Sophia" Children's Hospital, Athens, Greece
}

\section{Keywords \\ Gonadotropin-releasing hormone analogs · Children . \\ Adolescents · Precocious puberty · Transgender}

\begin{abstract}
This update, written by authors designated by multiple pediatric endocrinology societies (see List of Participating Societies) from around the globe, concisely addresses topics related to changes in GnRHa usage in children and adolescents over the last decade. Topics related to the use of GnRHa in precocious puberty include diagnostic criteria, globally available formulations, considerations of benefit of treatment, monitoring of therapy, adverse events, and long-term outcome data. Additional sections review use in transgender individuals and other pediatric endocrine related conditions. Although there have been many significant changes in GnRHa usage, there is a definite paucity of evidence-based publications to support them. Therefore, this paper is explicitly not intended to evaluate what is recommended in terms of the best use of $\mathrm{GnRHa}$, based on evidence and expert opinion, but rather to describe how these drugs are used, irrespective of any qualitative evaluation. Thus, this paper should be considered a narrative re-
\end{abstract}

\section{KARGER}

(c) 2019 S. Karger AG, Basel

E-Mail karger@karger.com

www.karger.com/hrp view on GnRHa utilization in precocious puberty and other clinical situations. These changes are reviewed not only to point out deficiencies in the literature but also to stimulate future studies and publications in this area.

(c) 2019 S. Karger AG, Basel

\section{Introduction}

Gonadotropin-releasing hormone analogs (GnRHa) have been used primarily in the treatment of central precocious puberty (CPP), in other conditions in which adult stature is compromised (those with a growth hormone $[\mathrm{GH}]$ deficiency, those with idiopathic short stature, or those who are small for gestational age [SGA]), or when pubertal hormone suppression is a part of the treatment regimen (transgender individuals). Noteworthy is the fact that the diagnosis of CPP appears to have become more common since the availability of GnRHa, similar to $\mathrm{GH}$ deficiency when biosynthetic $\mathrm{GH}$ first became available.

The goal of this update, which has been written by members designated by multiple, global pediatric endocrine societies (see List of Participating Societies), is to 
concisely address topics related to changes in GnRHa usage during childhood and adolescence since the previous consensus statement was published in 2009 [1]. It is not a consensus statement and hence has not been endorsed by any of the societies that designated participating authors. Clinical care using GnRHa has changed dramatically in recent years based on unpublished knowledge and discussions in numerous settings regarding daily clinical practice. This has been driven by many factors, most of which involve current demands for health care delivery, without verification by publications or controlled studies. Hence the need for a publication such as this.

Examples of changes include:

1. The lack of evidence for weight-based dosing previously recommended for depot forms of GnRHas

2. Change in the assessment of pituitary gonadotropins, with updated laboratory criteria

3. Fewer GnRH/GnRHa stimulation tests and a greater use of unstimulated luteinizing hormone (LH) concentrations that are above the prepubertal range, with less frequent insistence on stimulation testing by insurance companies in the USA

4. Less hormonal monitoring during therapy, particularly among patients on chronic therapy when other parameters including linear growth rates, lack of pubertal progression, and slowed progression of skeletal age are consistent with suppression, confirming efficacy

5. A shift to longer-acting forms

6. A lack of agreement regarding use of the $11.25-\mathrm{mg}$ and 30-mg 12-week preparation, again raising unanswered questions of how much suppression is needed for efficacy

7. Giving long-acting injections subcutaneously rather than intramuscularly with similar efficacy and much less pain

8. The additional cost of the minor surgical procedures to place and remove the implant at many locations

9. Continued lack of long-term outcome studies even though available information continues to support safety and efficacy

10. Greater usage of GnRHa among older patients with $\mathrm{CPP}$ despite advanced skeletal age $\mathrm{X}$-rays as well as in those with borderline early puberty or normally timed puberty, those with a short stature for their age, short pubertal GH-deficient individuals, and short pubertal individuals born SGA after pubertal onset

11. Use among transgender individuals including concerns mentioned above and highlighting concerns regarding impacts on bone mineral density and infertility.
Thus, this publication is considered timely and pertinent since clinical practitioners need to be aware of how GnRHa are being used. Hopefully, these topics will stimulate future prospective studies.

Sections include diagnostic criteria, formulations of GnRHa available globally for therapy, considerations of which patients will benefit from treatment, monitoring of GnRHa therapy, adverse events, long-term outcome data, and use in transgender individuals as well as usage for other situations. The primary focus is to highlight management changes since the 2009 update.

This project was initiated by the European Society for Pediatric Endocrinology (ESPE) Clinical Practice Committee (CPC) and the International Clinical Guidelines Committee (iCGC) at the 2016 ESPE meeting. E. Charmandari and P.A. Lee were asked to coordinate a $\mathrm{GnRHa}$ clinical update rather than a consensus statement. It was envisioned that this would be an effort from numerous interested pediatric endocrinology societies and that it would be accomplished via e-mails rather than face-toface meetings. K. Bangalore Krishna agreed to work as coordinator, provide e-mail communications as needed, and develop a repository of pertinent publications that were made available to all. The project leaders developed an outline and identified potential authors who then chose leaders for each outlined section. These in turn invited additional authors, aiming for representative participation from each society. Each subgroup was responsible for reviewing pertinent literature and writing their own section using knowledge of current practices and primarily recent publications. The section leads were given the responsibility of negotiating content among section authors. In addition, a writing committee was designated to integrate the sections and achieve agreement among the section leaders, and when necessary among section authors.

Grading of evidence was performed by a subgroup of the writing committee. The majority of literature citations have levels of evidence (LoE) graded at level 4 (uncontrolled cohort and case studies) or level 5 (expert opinions, case reports, and personal observations). References with higher levels of evidence are indicated by notations for LoE 1 (homogenous randomized control trials), 2 (meta-analyses or heterogeneous prospective trials), and 3 (case-control studies and retrospective cohorts) [2]. For each topic, an average LoE for the cited references was calculated as follows: section 1: 4.5 ; section 2: 3.9 ; section 3: 4.2; section 4: 4.5; section 5: 4.5; section 6: 4.3; section 7: 4.5 ; and section $8: 4.0$. 
Table 1. $\mathrm{LH}$ is the most valuable biochemical parameter used to diagnose CPP

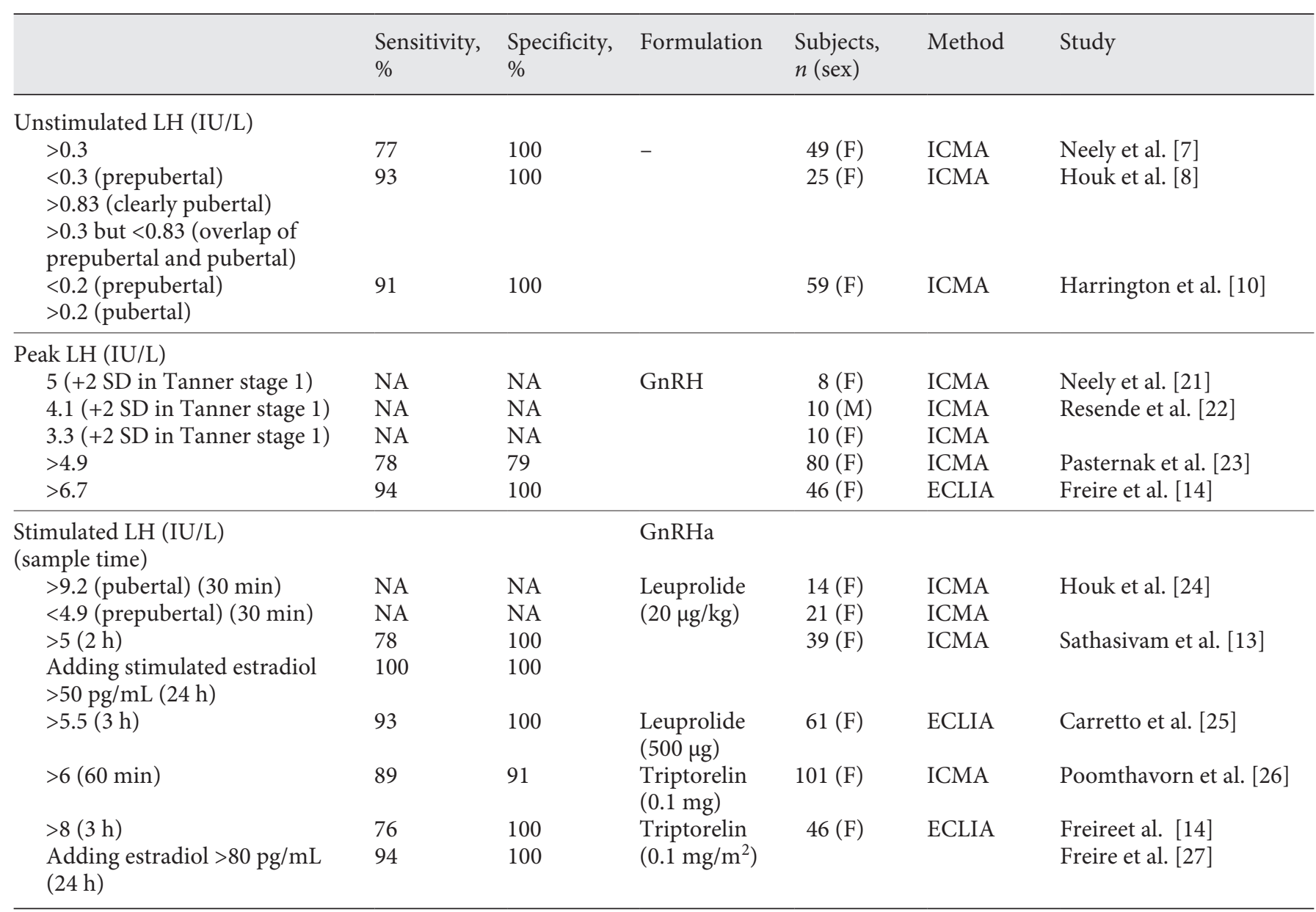

\section{Section 1: CPP - Diagnosis, Assessment, Natural History, and Racial Differences}

Challenges in diagnosing CPP involve: (1) differences in the normal age range of onset of puberty for different racial groups and (2) the decreasing age at onset of breast development in the general population [3]. Regarding (1), since patients from African-American and Hispanic racial and ethnic groups have an earlier normal range of onset of puberty, different age criteria should be considered when diagnosing CPP. Concerning (2), the earlier onset of breast development may not be progressive as typically occurs in CPP, and it is not necessarily caused by hypothalamic pituitary gonadal (HPG) activation. Thus, the documented decline in the age of thelarche over the past 5 decades does not mean that puberty is occurring earlier. To verify this, clinical progression and docu-

Use of GnRHa in Children: Update by an International Consortium mentation of pubertal HPG activation are necessary. Since the age of menarche has decreased only minimally during this interval $[4,5]$, it appears that earlier breast development in most instances is due to premature thelarche, which may be related to increased rates of obesity. Nevertheless, an increase in body mass index (BMI) may be one of many factors that accelerate biologic maturation and thus pubertal progression and menarche [4]. Internationally adopted children may have a greater likelihood (10- to 20-fold) of developing CPP [6].

$\mathrm{LH}$ is the best biochemical parameter used to diagnose CPP. When measured in ultrasensitive assays (ICMA with a sensitivity of $0.01 \mathrm{U} / \mathrm{L}$ or ECLIA with a sensitivity of $0.1 \mathrm{IU} / \mathrm{L}$ ), randomly obtained serum LH concentrations within the pubertal range confirm the diagnosis of CPP [7-9]. The most recent analyses suggest that a value $>0.2 \mathrm{IU} / \mathrm{L}$ can be considered a pubertal value [10] (Table

Horm Res Paediatr 2019;91:357-372 
1). However, in the setting of clinically progressive puberty, $\mathrm{LH}$ concentrations below the pubertal range do not exclude CPP, suggesting the need for GnRH or GnRHa stimulation testing. Likewise, there is still an overlap between prepubertal and pubertal levels reported by others, i.e., between 0.3 and 0.83 IU/L [11], suggesting the need for stimulation testing if the clinical presentation is not definitive. With stimulation testing, specific cut-offs for LH concentrations that indicate a pubertal HPG axis depend on the use of GnRH or GnRHa as the stimulus, the sampling time, and the assay employed (Table 1). Caution should be exercised when interpreting gonadotropin concentrations in children younger than 2 years, since baseline and peak LH concentrations are higher during infancy and can lead to a misdiagnosis of CPP [11, 12]. Random estradiol concentrations may not verify pubertal activation but may improve the sensitivity of stimulation testing when obtained $18-24 \mathrm{~h}$ after $\mathrm{GnRH} / \mathrm{a}$ administration $[13,14]$.

Findings from transabdominal pelvic ultrasonography are not a diagnostic criterion for CPP. Nonetheless, uterine and ovarian enlargements are consistent with precocious puberty because uterine growth reflects estrogen stimulation, while gonadotropin stimulation is required for growth of the ovaries. Uterine lengths $>3.5-4 \mathrm{~cm}$ and ovarian volumes $>2 \mathrm{~mL}$ are consistent with puberty $[15,16]$.

In children diagnosed with CPP, central nervous system magnetic resonance imaging (MRI) should be performed in all boys and at least in all girls who are 6 years or younger to exclude intracranial pathology, which has been reported to occur in up to $6.3 \%$ of girls [17] and $38 \%$ of boys [18] with CPP. However, a meta-analysis of MRI findings in CPP demonstrated that only $1.6 \%$ of girls had CNS abnormalities that required an intervention [19]. The goal of imaging is to identify pathologic causes of CPP, which are less likely when there is a family history, genetic findings, or an international adoption, particularly from the developing world. A consequence of obtaining MRI is that there may be incidental findings of unknown significance. Current recommendations are to discuss the pros and cons of MRI scanning with the parents to assist them in making an informed decision [20].

LH is the most valuable biochemical parameter used to diagnose CPP. Studies have shown the specificity and sensitivity of stimulated and unstimulated LH concentrations in diagnosing CPP (Table 1 ) $[7,8,10,13,14$, 21-27].

\section{Section 2: Available GnRHa and Current Therapeutic Regimens}

Long-acting GnRHa are the standard of care for the treatment of CPP. They generally have been understood to exert their effect by occupying the GnRH receptor resulting in a desensitization of pituitary gonadotrophs [28] with subsequent suppression of gonadal steroid secretion. Interestingly, animal studies have shown that the total number of membrane receptors during GnRHa treatment does not decrease to below $30 \%$ of baseline values, which should result in a normal sensitivity of the gonadotrophs to native $\mathrm{GnRH}$. It has been shown that there are sustained increased levels of free $\alpha$-subunit during $\mathrm{LH}$ and follicle-stimulating hormone suppression by the histrelin implant as well as monthly depot GnRHa preparations [29]. Thus the GnRH receptors are not totally suppressed, but rather they alter their function to produce increased amounts of free $\alpha$-subunit instead of both components of the glycoprotein hormones [30].

Previously, monthly (4-week) depot GnRHa were most frequently used. However, additional 3-monthly (12-week) and 6-monthly (24-week) formulations, as well as subcutaneous implants, have become available over the past $\sim 10$ years. The depot options (leuprolide and triptorelin) are sustained-release formulations administered in various doses and intervals, whereas the subcutaneous histrelin implant requires a minor surgical procedure for insertion and removal and is marketed for annual use. This implanted preparation has been shown to be effective longer, which has the potential to decrease the cost and number of procedures [31]. The starting dose of monthly depot leuprolide acetate approved for pediatric use in the USA ranges from 7.5 to $15 \mathrm{mg}$ and for the 12 -week preparation is either 11.25 or $30 \mathrm{mg}$. Doses are increased if needed to achieve adequate suppression. In Europe and Asia, leuprolide dosing is standardized at $3.75 \mathrm{mg}$ i.m. every 28 days [32, 33]. Weight-based dosing is no longer recommended for the depot forms of leuprolide acetate. The starting dose of triptorelin pamoate is typically $3.75 \mathrm{mg}$ every 28 days and may be titrated up as necessary (to $11.25 \mathrm{mg}$ ) [34, 35]. Triptorelin pamoate $(22.5 \mathrm{mg})$ administered at 6-month intervals is effective, but long-term outcome data are not yet available [36]. Prospective extension studies during therapy have demonstrated HPG axis suppression within days of histrelin implant insertion [37], within weeks for higher doses of depot forms, and within 3 months for lower doses and longer-acting depot forms [34, 36, 38]. Biochemical efficacy may be demonstrated by measuring unstimulated
Bangalore Krishna/Fuqua/Rogol/Klein/ Popovic/Houk/Charmandari/Lee 
Table 2. Available GnRHa preparations (may vary in different countries)

\begin{tabular}{lcc}
\hline GnRHa preparation & Dosing \\
\hline Leuprolide acetate & 1-month depot & $3.75 \mathrm{mg}$ \\
& & $7.5 \mathrm{mg}$ \\
& & $11.25 \mathrm{mg}$ \\
& 3-month depot & $11.25 \mathrm{mg}$ \\
& & $30 \mathrm{mg}$ \\
Triptorelin pamoate & 1-month depot & $3.75 \mathrm{mg}$ \\
(embonate) & 6-month depot & $11.25 \mathrm{mg}$ \\
& $22.5 \mathrm{mg}$ \\
Histrelin acetate & 12-month implant & $50 \mathrm{mg}$ \\
& & $(65 \mu \mathrm{gg} /$ day $)$ \\
\hline
\end{tabular}

ultrasensitive LH or stimulated LH concentrations or sampling after a therapeutic depot injection. However, it is important to note that unstimulated LH concentrations above the prepubertal range commonly do not indicate a lack of suppression [39]. Clinical evidence of efficacy includes a slowing growth velocity, regression or lack of progression of clinical signs of puberty, a progressive decrease in the ratio of BA to CA (BA/CA), and an increase in the predicted adult height $(\mathrm{PAH})$. However, the extent of suppression required for clinical efficacy remains unclear. No differences in clinical indices of pubertal progression were seen in studies comparing monthly preparations and 2 doses of the 3-monthly preparations of leuprolide depot [34, 40]. Prospective comparison studies are needed to establish whether there are differences in efficacy among the GnRHa in use today. Clinicians should discuss all of the available options with patients and families, including the expected duration of the therapy, the frequency of administration, and potential short-term and long-term side effects. Considerations may include an implant for patients with an extreme needle phobia and those with special needs, whereas others may opt for extended-release injectable formulations. The sustainedrelease GnRHa preparations are similar in annual cost and may improve compliance. Table 2 contains a summary of the most commonly used GnRHa preparations.

\section{Section 3: Considerations for GnRH Analog Therapy in Children with CPP: to Treat or Not to Treat}

The onset of thelarche in 7- to 8-year-old females is increasingly common $[41,42]$ and it is frequently associated with obesity [3]; however, pubertal gonadotropin se-

Use of GnRHa in Children: Update by an International Consortium cretion in these girls has not been clearly documented. The physical changes of puberty at this age may be temporary, commonly followed by a slow progression or development within the range of normal puberty, and they culminate in achievement of a normal adult height $(\mathrm{AH})$ without therapeutic intervention [43].

Early GnRHa studies treating CPP primarily included patients who were young (e.g., mean age of onset: 6 years) [44] and also demonstrated a rapid progression of pubertal changes. Subsequently, GnRHa use has considerably expanded to include those with a minimally early onset of puberty (e.g., girls ages 7-9 years) who may not necessarily derive similar significant clinical benefits from treatment.

To determine the benefit of GnRHa treatment for individual patients, the following factors should be considered:

1. Girls younger than 7 years and boys younger than 9 years showing progressive central puberty, or who are more advanced in pubertal development (e.g., sexual maturation rating [SMR; i.e., Tanner stage] 3 breast or genital development) with rapid linear growth apparent at their first visit merit GnRHa treatment. A brisk tempo of pubertal progression increases the risk of adult short stature.

2. For girls older than 7 years with SMR 2 breast development, an observation period of 4-6 months is suggested to assess the tempo of pubertal progression before offering treatment. Height outcomes are much less clear for girls with pubertal onset at age 7 years or older. The increase in $\mathrm{AH}$ over the predicted height at the onset of therapy varied in one comprehensive review summarizing 29 studies, i.e., from 2 to $10 \mathrm{~cm}$ [43], suggesting that some but not all patients benefit from therapy starting at this age. Another report, i.e., a meta-analysis of 6 studies involving 332 girls treated between the ages of 7 and 10 years reported no increase in $\mathrm{AH}$ [45]. In fact, most untreated girls with CPP who were not treated with $\mathrm{GnRHa}$ reached a normal AH [46-48], although some were shorter than their midparental height range.

3. There have been concerns about psychological morbidity of CPP with early menses, but adverse behavioral profiles occurring with early maturation may not be as common as earlier described $[49,50]$. Families should be informed that, when puberty starts close to age 8 years or later, menarche usually does not occur for another 2.5-3 years, so an onset before age 10 years is unlikely $[4,51,52]$. Preparation of early-maturing girls for the onset of menses by a calm and reassuring 
parent is a key aid to lessening psychological distress. Suppression of menses can still be an option if menarche occurs early and is stressful for the child.

The following are suggestions for an informed discussion of possible GnRHa treatment for an early-maturing girl (onset: 7-9 years of age):

1. If the height is above average, with a skeletal age that is not markedly advanced, the AH will probably be normal and may not significantly improve with treatment.

2. Adverse psychosocial stress may not occur from early puberty but, if it does, GnRHa treatment may not alleviate such stress.

3. Puberty may progress slowly so that menses may not occur as early as feared. Observation for 4-6 months will help to decide whether a child's puberty is progressing rapidly.

4. Treatment is expensive, and in addition there is the stress associated with having a condition requiring a pharmacologic intervention, clinic visits, and periodic injections or implant insertion/removal, among other factors.

5. Several studies have failed to find any benefit in terms of height in girls treated after age 8 years, and some girls may even lose height as a result of treatment [5359].

Discussion with the parents and child about the goals of treatment (or not) encourages thoughtful consideration of therapeutic restraint, reassurance, and observation, since the benefit of treatment may be uncertain in this age group [60].

Among males, a similar rationale could be applied in consideration of treatment among those who have a borderline early pubertal onset. Regarding height, unless the skeletal age is markedly advanced, it is unclear whether the adult stature will be increased by GnRHa therapy, especially if the treatment interrupts a robust pubertal growth spurt.

\section{Section 4: Monitoring GnRHa Treatment}

The goals of GnRHa therapy for patients with CPP are to halt pubertal progression and progressive physical development, including height for age and differences from age- and sex-matched peers, and to preserve or reclaim the AH potential. Short-term clinical assessment should occur every 3-6 months to evaluate for stabilization of physical changes $[36,61,62]$. The height change velocity generally slows to prepubertal rates within months of the onset of therapy [63, 64]. The development of pubic hair may stabilize or regress but it is not an accurate indicator of HPG axis suppression since adrenarche may have occurred. The rate of skeletal age advancement should decrease after 6 months of therapy, with a concomitant gradual increase in the $\mathrm{PAH}$, assuming a reasonable growth rate. The HPG axis can be evaluated by measuring unstimulated or stimulated (following $\mathrm{GnRH}$ or GnRHa administration) serum $\mathrm{LH}$, sex steroids, or urinary gonadotropin concentrations [24, 65-68]. It is recognized that unstimulated LH concentrations above the prepubertal range do not necessarily indicate a lack of suppression, while concentrations within the prepubertal range likely indicate suppression. However, the lack of correlation between biochemical measurements during treatment and $\mathrm{AH}$ outcomes does not support routine biochemical testing in all patients $[39,61,69]$.

Indicators of treatment failure, including clinical pubertal progression, a lack of growth deceleration, and continued excessive bone age advancement, should prompt reassessment. Treatment failure may be confirmed on clinical grounds alone or verified by $\mathrm{GnRHa}$ stimulated LH concentrations minimally $>4$ IU/L [39, 69]. The adherence to and timing of GnRHa administration should be assessed when treatment fails, with confirmation that the precocity is CPP rather than a $\mathrm{GnRH}$ independent cause. If increasing the dose of GnRHa is indicated, decreasing the dosing interval is an option.

\section{Discontinuation of GnRHa Therapy in CPP}

No single clinical variable can determine the best age to discontinue GnRHa. The decision to discontinue treatment should be individualized, and it is appropriate to inquire about the parents' and the patient's perceptions of readiness to stop, since it can be anticipated that pubertal maturation will resume within months. Menses may occur from several months to more than 2 years after stopping GnRHa treatment. It is reasonable to discontinue therapy at a time such that puberty progresses concurrently with that of the child's peers. Increased AH has been associated with longer treatment [56, 70-72]. However, at some point further GnRHa therapy does not produce further gains in $\mathrm{AH}$, and treatment beyond a bone age of 12.5 years in girls and 14.0 years in boys may at best result in a minimal increase in height $[43,56,71,73]$. Hence, the timing of GnRHa treatment discontinuation is based on patient readiness for resumption of puberty, recent growth rates and shifts in height prediction rather than on bone age alone. The patient's AH typically ends 
up being greater than the $\mathrm{AH}$ predicted when the GnRHa treatment is initiated but less than the predicted height when the therapy is discontinued [71-74].

\section{Section 5: GnRHa Adverse Effects}

Adverse effects of GnRHa therapy are rare, and the associations of most reported adverse events with the GnRHa molecule itself are unclear. Decades of experience have shown that GnRHa treatment is both safe and efficacious. The following comments relate to specific adverse events:

1. Allergic or local reactions to GnRHa preparations occur rarely and have been inadequately documented. Local reactions associated with suspensions and histrelin implants occur infrequently. Sterile abscess formation after depot injections is likely a reaction to the inert polymer $[53,75]$. Fracture of implants on removal, including the risk of leaving active drug, occurs in $22-28 \%$ of cases, more frequently after implants have been left in place for longer than 2 years $[31,62,76$, 77].

2. Withdrawal bleeding due to falling estrogen concentrations may occur after the initiation of GnRHa treatment in girls having a significant endometrial lining. Occurrence beyond 2 months of treatment suggests that gonadotropin suppression has not been achieved or another etiology.

3. Hot flashes are occasionally seen in the initial phases of GnRHa treatment in girls with CPP. This is due to declining estrogen concentrations, but it resolves quickly.

4. Convulsions have been reported in patients receiving GnRHa in postmarketing reports and have included patients with a history of seizures, epilepsy, cerebrovascular disorders, central nervous system anomalies, or tumors and patients on concomitant medications that have been associated with convulsions, such as bupropion and selective serotonin reuptake inhibitors. Convulsions have also been reported in patients in the absence of any of the conditions mentioned above. The data in the literature are limited, consisting of sporadic case reports [78].

5. A prolonged QT interval associated with GnRHa has not been reported in women or children. This has been reported in adult males treated with GnRHa for prostate cancer, attributed to changes in circulating testosterone concentrations and postulated to be related to congenital long QT syndrome, increased body weight, a reduction in insulin sensitivity, dyslipidemia, concomitant medications, cardiac disease, electrolyte abnormalities, and diuretic therapy [79, 80]. For pediatric cases, a screening ECG is recommended only if the individual is receiving other medications known to cause a prolonged QT interval, has a history of congenital heart disease, arrhythmia, or long QT syndrome, has a family history of long QT syndrome or sudden cardiac death, or has symptoms suggestive of long QT syndrome, including syncope $[81]^{1}$.

6. Slipped capital femoral epiphysis has been reported in a small number of patients, occurring during $\mathrm{GnRHa}$ treatment or after cessation of GnRHa therapy [82]. As during normally timed puberty, slipped capital femoral epiphysis may be related to a lack of adequate sex hormone exposure at a critical period of bone formation. Prompt evaluation and management are indicated.

7. Pituitary apoplexy is a rare complication reported in men with prostate cancer treated with GnRHa for androgen deprivation and it develops within hours after the GnRHa administration [83]. In 14 males and $1 \mathrm{fe}$ male, all were found to have pathologic gonadotropin secreting adenomas, suggesting the potential to precipitate pituitary apoplexy. There have been no reported cases of pituitary apoplexy in children or adolescents.

\section{Section 6: Long-Term Outcomes}

\section{General Health and Wellness}

While studies indicate that early normal puberty is associated with more frequent risk-taking behaviors and functional symptoms in older adolescents [84], there is insufficient data to determine whether those with CPP with or without GnRHa therapy show such behaviors. GnRHa therapy for early puberty may have adverse metabolic profiles as reported among girls with early normal puberty $[84,85]$. These girls with early normal puberty, assumed to be related to a longer chronic estrogen exposure, have an increased risk of breast cancer [86] and unverified increased risks of obesity, type 2 diabetes mellitus, cardiovascular disease, and other malignancies [87]. These reports do not control for secular trends in obesity

B.S. Miller and M. Kamboj of the Drug and Therapeutics Committee of the Pediatric Endocrine Society. 
and exposure to endocrine disrupting chemicals. The impact of the addition of GnRHa therapy on these risks is unknown.

\section{Reproductive Function and Fertility}

There is no substantiated evidence that GnRHa treatment for CPP impairs reproductive function or reduces fertility. In most girls, gonadal function is restored promptly after cessation of therapy, with subsequent menarche and regular ovulatory menstrual cycles $[32,58$, 88]. Using structured interviews among 135 adult women with CPP treated with GnRHa, 61 women with untreated $\mathrm{CPP}$, and 466 controls matched for age, education, marital status, and parity [89], pregnancy was uneventful in $90 \%$ of all 3 groups. Unassisted pregnancy rates were similar in GnRHa-treated women with CPP and controls (>90\%), while, in this series, untreated women with a history of CPP were more likely to require assisted fertility therapy. In another group of 46 women with CPP (aged 19.0-31.3 years), $71 \%$ experienced regular, spontaneous menstrual cycles, with normal fertility and offspring. The menstrual history is reported to be normal in all women previously treated with GnRHa for CPP, except for those with organic causes such as anterior pituitary lesions [56]. The outcomes of 113 pregnancies included 97 uneventful pregnancies with healthy children, 5 elective abortions, and 11 early miscarriages.

Limited data exist on reproductive function in males treated for CPP but they include normal serum testosterone $[32,90]$, gonadotropin concentrations, and semen analysis [90]. Data on paternity rates and fertility are not available.

\section{Polycystic Ovary Syndrome}

There is no clear evidence that girls with treated or untreated CPP are more likely to develop polycystic ovary syndrome (PCOS) than their age-matched peers $[55,84$, 89, 91-96]. Reports include a significant incidence of PCOS in former CPP patients [97], with a lower prevalence of PCOS in GnRHa-treated girls than in nontreated girls $(17.2 \%, n=33$, vs. $30.8 \%, n=14)$, with elevated DHEAS and androstenedione concentrations in $56 \%$ of those receiving GnRHa versus $23.6 \%$ among those who did not [55]. Another report using single logistic regression analysis found that $\mathrm{GnRHa}$ treatment correlated with PCOS ( $p=0.03$ ) when comparing $36 \%$ of 25 girls diagnosed with PCOS who had been previously treated with GnRHa for CPP with 14.5\% of 55 girls who had had CPP untreated with GnRHa [95]. However, these percentages are high and it is unclear whether there was rep- resentative sampling and whether diagnostic criteria fit published incidence studies that indicate a lower frequency [98]. Further, since data do not determine whether hyperandrogenemia preceded the diagnosis or treatment of $\mathrm{CPP}$, it is possible that this is a preselected biased group. Future studies should use the Recent International Consortium Update [99] to classify both treated and untreated CPP subjects.

\section{Psychological Outcome}

Some early studies suggested that psychological and social problems occur among girls with CPP [100-102], citing anxiety about breast development and other physical differences from peers. Subsequent reports have not substantiated such findings. A study of 19 girls with CPP, 22 girls with premature adrenarche, and 21 girls with early normal puberty found no significant differences in peer acceptance or child psychological adjustment [103]. No significant differences in anxiety, depression, somatization, attention deficit, offensive behavior, or academic performance were found before or after 24 weeks of GnRHa treatment in those with CPP. Using adaptation profiles, social competency was not significantly higher than that of peers before treatment onset [101]. Another report did not show significantly more behavior problems in girls with CPP than in age-matched healthy controls [50]. In contrast, another report found that GnRHatreated girls with CPP had higher total scores of physical and psychological stress with a depressive component before GnRHa treatment, and stress scores were reduced in all patients after a year of GnRHa treatment [104]. The lack of uniformity regarding the psychological impact of GnRHa treatment in children with CPP is not surprising since individuals are unique, with both innate and environmental factors influencing responses to pubertal changes. Thus, there is no basis for expecting a different incidence of psychological problems among those who had CPP with or without therapy than in the general population, although more research is needed.

\section{Impact on Weight}

Although it has been suggested that weight gain occurs with GnRHa treatment of CPP [105-108], a reduction in BMI has also been reported [109]. Long-term studies have not supported the concept of treatment-related weight gain when comparing BMI SD scores before and after therapy, even though there is an increased prevalence of being overweight and obese at diagnosis [58, 109-112]. The weight status of women who had CPP resembles that of the general population [113]. A higher 
BMI percentile at presentation and during therapy was associated with being overweight or obese during young adulthood. Thus, GnRHa treatment appears not to influence the long-term progression of these children toward obesity during adolescence or adulthood.

\section{Bone Mineral Density}

Children with CPP often have an elevated bone mineral density (BMD) for their age at diagnosis. GnRHa treatment slows mineral accrual, but after discontinuation BMD appears not to be significantly different from that of their peers by late adolescence. Reports of BMD among children and adolescents verified a decrement in $\mathrm{BMD}$ at the achievement of near $\mathrm{AH}$, while accrual resumed after therapy, regardless of whether or not calcium supplementation was given. By late adolescence, all subjects had BMD within the normal range $[114,115]$. A recent report of assessment during therapy suggested structural alterations, but those adolescents were not evaluated after stopping therapy [116]. Data suggest that, while children treated with GnRHa have a diminished bone accrual during treatment, it is likely that BMD is within the normal range after cessation of therapy by late adolescent ages.

\section{Section 7: Use of GnRHa in the Management of Transgender Adolescents}

Current guidelines include criteria for initiating treatment with GnRHa $[117,119]$. Therapy should only be initiated after the individual has begun clinical puberty (breast or genital SMR 2 and testicular volume $\geq 4 \mathrm{~mL}$ ) [117]. In transgender boys, GnRHa may be continued until subsequent testosterone therapy has resulted in serum concentrations within the adult reference range. In contrast, adult dose estrogens frequently do not suppress testosterone production in transgender girls, so GnRHa therapy may be continued if the testes remain in situ [117]. Initial treatment of young transgender adolescents with GnRHa is commonly recommended to prevent the development of undesired secondary sex characteristics $[117,118]$. Such reversible treatment enables an extended diagnostic phase for gender clarification before electing to proceed with further gender-affirming hormone treatment $[119,120]$.

GnRHa suppress the HPG axis, resulting in a decreased testicular volume and the cessation of menses $[121,122]$. Additional changes include a decrease in height SDS and $\mathrm{BMD}$ along with alterations in body composition consist-

Use of GnRHa in Children: Update by an International Consortium ing of increased body fat and a decreased lean body mass [121]. The impact on BMD is concerning since lumbar spine Z-scores at age 22 years were found to be lower than those observed prior to treatment $[122,123]$, suggesting a possible permanent decrement in BMD. Thus, it is unclear how long GnRHa can safely be administered. The effects of GnRHa on adolescent brain maturation are unclear. GnRHa therapy prevents maturation of primary oocytes and spermatogonia and may preclude gamete maturation, and currently there are no proven methods to preserve fertility in early pubertal transgender adolescents. Care for each adolescent must be individualized, with awareness of gender fluidity and ethical guidelines [124].

\section{Section 8: Use of GnRHa in Other Conditions}

\section{GH Deficiency}

In GH-deficient children, the addition of GnRHa may be considered in 2 situations:

1. Children treated for malignancy with a resultant $\mathrm{GH}$ deficiency and CPP. In this group of patients, GnRHa and GH therapy increases the PAH and the AH [125128].

2. Children with a GH deficiency who have not experienced catch-up growth at the onset of puberty since an insufficient height at pubertal onset will result in a short $\mathrm{AH}$. Therapeutic combinations in this situation have involved increased GH doses [129], the addition of aromatase inhibitors [130], and the addition of GnRHa to halt pubertal progression and allow more $\mathrm{GH}$-augmented prepubertal growth. The addition of a GnRHa to $\mathrm{GH}$ at the onset of puberty and treatment for at least 2 years resulted in gains of $\mathrm{AH}$ ranging from 6 to $9 \mathrm{~cm}(\sim 1-1.5 \mathrm{SD})[131,132]$. These situations are not the usual practice for patients diagnosed with an isolated GH deficiency and treated in a timely manner with GH. Such use of GnRHa or aromatase inhibitors remains controversial and is not standard of care.

\section{Non-GH-Deficient Short Stature}

Adolescent growth has been the focus of several interventions aimed at increasing the amplitude of the adolescent growth spurt. Favorable results with GnRHa in precocious puberty have encouraged attempts to increase the duration of the adolescent growth spurt by delaying normal puberty in short subjects using GnRHa with or without GH treatment. Controlled prospective [133, 
134], uncontrolled prospective [135], and retrospective analyses [136] indicate that the use of GnRHa alone in these cases lacks efficacy. In a randomized, placebo-controlled trial in short adolescents with normally timed puberty (most having idiopathic short stature), 18 boys and 32 girls with baseline predicted $\mathrm{AH}$ of $-3.3 \pm 1.2 \mathrm{SD}$ were randomized to receiving either placebo or $\mathrm{GnRHa}$. Those who received GnRHa had a 0.6 SD increase in $\mathrm{AH}(\sim 4.2$ $\mathrm{cm}$, range $1.7-6.7 \mathrm{~cm})$ compared to the predicted $\mathrm{AH}$ at baseline $(p=0.01)$ after a mean duration of $3.5 \pm 0.9$ years; however, they also demonstrated a significant reduction in BMD [115]. A recent study of GnRHa treatment of idiopathic short stature during puberty reported that $\mathrm{AH}$ in treated girls was significantly greater than among untreated girls but not boys [137]. It should be noted, however, that the treated ( 21 girls and 7 boys) and untreated (14 girls and 17 boys) groups were not matched, with the latter group being those offered but declining GnRHa therapy. There was considerable variation in response to therapy, and the group size for girls may have been sufficiently large to yield a statistically significant response, while the group of boys may have been too small. Some studies have shown that combined GH and GnRHa treatment for 3 or more years may result in a greater increase in AH [138-142], particularly in adopted girls $[140,141]$.

However, a recent publication regarding combined therapy found that, not unexpectedly, patients treated with the combination grew more slowly than those receiving GH alone during the first 2-3 years of treatment. Statistical comparison of near AH SDS between the 2 groups was not possible [143]. In addition to height, the cost-benefit of such invasive treatments should also be considered, and further larger, long-term, and adequately powered clinical trials, focusing on efficacy, safety, and clinical significance, are needed to fully evaluate the combination of GH and GnRHa in short adolescents. Meanwhile, these approaches should be considered as experimental.

\section{Small for Gestational Age}

Pubertal height gain is less than expected in children born SGA, as a result of an earlier onset of puberty, an earlier peak height velocity, and accelerated bone maturation $[144,145]$. Evidence suggests that combined GH and GnRHa treatment may increase AH in SGA children who are short at the start of puberty $(<140 \mathrm{~cm})$ and who have a subnormal PAH [146]. The mean height gain from the onset of puberty until $\mathrm{AH}$, including the height gain during 2 years of GnRHa treatment, was $25.4 \mathrm{~cm}$ in girls and
$33.0 \mathrm{~cm}$ in boys, i.e., $6.6 \mathrm{~cm}$ more than girls and boys treated with GH alone [147]. Hence, although the data are limited, it is appropriate to consider the potential advantages and disadvantages of treatment with GH and $\mathrm{GnRHa}$ in this population.

\section{Fertility Preservation}

GnRHa treatment has been administered just before and during chemotherapy to minimize the risk of premature ovarian insufficiency by reducing exposure to cytotoxic agents and protecting the developmental process of primordial follicles [148]. Systematic reviews and meta-analyses show a higher recovery rate of cyclic ovarian function after chemotherapy in patients treated with GnRHa before and during chemotherapy than untreated groups [149-154]. However, the results were mixed depending on the type of tumor [155-159]. Additionally, there are no long-term randomized, controlled studies. Thus, the efficacy of fertility preservation by $\mathrm{GnRHa}$ in adults is still controversial. Furthermore, there are few efficacy data in adolescent girls $[160,161]$. Because primordial follicles and eggs do not originally have receptors for GnRH and thus GnRHa cannot directly protect primitive follicles from chemotherapy toxicity [160], and because the efficacy of fertility preservation of $\mathrm{GnRHa}$ is still controversial, the use of GnRHa before and during chemotherapy for all adolescents with malignancies is currently not recommended outside of clinical trials.

\section{Autism, Problematic Behavior, and Developmental Impairment}

GnRHa treatment cannot be recommended for autism as there is no validated evidence of efficacy. A single article reported that GnRHa usage in both prepubertal and pubertal children with autism improved behavioral symptoms (e.g., reduced aggressiveness and inappropriate sexual behavior) in the short term [162]. Attempts to replicate these data have not been successful. There is no evidence of any longstanding improvement in patients' inappropriate behavior or use of such therapy in children with autism [163]. Although GnRHas have been used to treat patients with developmental problems (i.e., males who masturbate in public and females unable to care for themselves during menstruation), preventing pubertal progression can be seen, at best, as a temporary measure. 


\section{Conclusion}

While much of the information discussed above is not published in well-controlled studies or even published at all, this concise summary has included items that are pertinent to the diagnosis and care of those treated with GnRHa. It is clear that many changes have occurred in the clinical use of GnRHa without the benefit of peer-reviewed publications. These changes appear to have been driven by an understanding that detailed testing may not be necessary to diagnose CPP or to monitor GnRHa therapy as well as the demands for pragmatic clinical approaches. Hence, when a single LH verifies pubertal secretion or when the clinical findings for patients on treatment are consistent with suppression, additional testing may be considered unnecessary. Nevertheless, carefully conducted outcome studies, preferably prospective controlled studies, are needed to verify dosing, monitoring, and long-term outcomes. Likewise, research is required to determine a basis for weight-based dosing of depot preparations, to compare efficacy and safety profiles of depot injections, and to assess subcutaneous versus intramuscular administration, as well as to examine other unpublished changes that are listed in the Introduction.

\section{Disclosure Statement}

The authors declare no conflict of interests relevant to this paper.

\section{List of Participating Societies}

Pediatric Endocrine Society (PES), ESPE, Australasian Pediatric Endocrine Group (APEG), Asia Pacific Paediatric Endocrine Society (APPES), African Society for Paediatric and Adolescent Endocrinology (ASPAE), Japanese Society for Pediatric Endocrinology (JSPE), Sociedad Latinoamericana de Endocrinologia Pediatrica (SLEP), Chinese Society for Pediatric Endocrinology and Metabolism (CSPEM), Indian Society for Paediatric and Adolescent Endocrinology (ISPAE), Canadian Pediatric Endocrine Society (CPES), and Sociedad Mexicana de Endocrinología Pediátrica (SMEP).

\section{Section Authors}

Section 1: Analía Verónica Freire and María Gabriela Ropelato (SLEP); Muhammad Yazid Jalaludin (APPES); Joyce Mbogo (ASPAE); Christina Kanaka-Gantenbein (ESPE); and Xiaoping Luo (CSPEM).

Section 2: Erica A. Eugster, Karen O. Klein, Maria G. Vogiatzi, Kent Reifschneider, and Vaneeta Bamba (PES); and Cecilia Garcia Rudaz (APEG).

Section 3: Paul Kaplowitz, Philippe Backeljauw, and David B. Allen (PES).

Section 4: Mark R. Palmert (CPEG and PES); Jennifer Harrington (CPEG); Gil Guerra-Junior (SLEP); Takara Stanley (PES); Margarita Torres Tamayo and América Liliana Miranda Lora (SMEP); and Anurag Bajpai (ISPAE).

Section 5: Lawrence A. Silverman, Vaneeta Bamba, Bradley S. Miller (PES); Archana Dayal (ISPAE); and Reiko Horikawa (APPES and JSPE).

Section 6: Sharon Oberfield and Alan D. Rogol (PES); Toshihiro Tajima (JSPE); Jadranka Popovic (ESPE and PES); and Cecilia Garcia Rudaz (APEG).

Section 7: Selma F. Witchel, Stephen M. Rosenthal, and Courtney Finlayson (PES); Sabine E. Hannema (ESPE); and María-Fernanda Castilla-Peón (SMEP).

Section 8: Maria G. Vogiatzi (PES); Muhammad Yazid Jalaludin (APPES); Reiko Horikawa (APPES and JSPE); Veronica Mericq (SLEP); and Patricia Guadalupe-Medina Bravo (SMEP).

\section{References}

1 Carel JC, Eugster EA, Rogol A, Ghizzoni L, Palmert MR, Antoniazzi F, et al.; ESPE-LWPES GnRH Analogs Consensus Conference Group. Consensus statement on the use of gonadotropin-releasing hormone analogs in children. Pediatrics. 2009 Apr;123(4):e752-62.

2 Burns PB, Rohrich RJ, Chung KC. The levels of evidence and their role in evidence-based medicine. Plast Reconstr Surg. 2011 Jul; 128(1):305-10

3 Biro FM, Greenspan LC, Galvez MP, Pinney SM, Teitelbaum S, Windham GC, et al. Onset of breast development in a longitudinal cohort. Pediatrics. 2013 Dec;132(6):1019-27.

4 Biro FM, Pajak A, Wolff MS, Pinney SM, Windham GC, Galvez MP, et al. Age of Menarche in a Longitudinal US Cohort. J Pediatr Adolesc Gynecol. 2018 Aug;31(4):339-45.
5 Aksglaede L, Sørensen K, Petersen JH, Skakkebaek NE, Juul A. Recent decline in age at breast development: the Copenhagen Puberty Study. Pediatrics. 2009 May;123(5):e932-9.

6 Teilmann G, Petersen JH, Gormsen M, Damgaard K, Skakkebaek NE, Jensen TK. Early puberty in internationally adopted girls: hormonal and clinical markers of puberty in 276 girls examined biannually over two years. Horm Res. 2009;72(4):236-46.

7 Neely EK, Wilson DM, Lee PA, Stene M, Hintz RL. Spontaneous serum gonadotropin concentrations in the evaluation of precocious puberty. J Pediatr. 1995 Jul;127(1):47-52.

8 Houk CP, Kunselman AR, Lee PA. Adequacy of a single unstimulated luteinizing hormone level to diagnose central precocious puberty in girls. Pediatrics. 2009 Jun;123(6):e1059-63.
9 Martinez-Aguayo A, Hernández MI, Capurro T, Peña V, Avila A, Salazar T, et al. Leuprolide acetate gonadotrophin response patterns during female puberty. Clin Endocrinol (Oxf). 2010 Apr;72(4):489-95.

10 Harrington J, Palmert MR, Hamilton J. Use of local data to enhance uptake of published recommendations: an example from the diagnostic evaluation of precocious puberty. Arch Dis Child. 2014 Jan;99(1):15-20.

11 Bizzarri C, Spadoni GL, Bottaro G, Montanari G, Giannone G, Cappa M, et al. The response to gonadotropin releasing hormone $(\mathrm{GnRH})$ stimulation test does not predict the progression to true precocious puberty in girls with onset of premature thelarche in the first three years of life. J Clin Endocrinol Metab. 2014 Feb;99(2):433-9. 
12 Vestergaard ET, Schjørring ME, Kamperis K, Petersen KK, Rittig S, Juul A, et al. The follicle-stimulating hormone (FSH) and luteinizing hormone (LH) response to a gonadotropin-releasing hormone analogue test in healthy prepubertal girls aged 10 months to 6 years. Eur J Endocrinol. 2017 Jun;176(6):74753.

13 Sathasivam A, Garibaldi L, Shapiro S, Godbold J, Rapaport R. Leuprolide stimulation testing for the evaluation of early female sexual maturation. Clin Endocrinol (Oxf). 2010 Sep;73(3):375-81.

14 Freire AV, Escobar ME, Gryngarten MG, Arcari AJ, Ballerini MG, Bergadá I, et al. High diagnostic accuracy of subcutaneous Triptorelin test compared with GnRH test for diagnosing central precocious puberty in girls. Clin Endocrinol (Oxf). 2013 Mar;78(3):398404.

15 de Vries L, Horev G, Schwartz M, Phillip M. Ultrasonographic and clinical parameters for early differentiation between precocious puberty and premature thelarche. Eur J Endocrinol. 2006 Jun;154(6):891-8.

16 Sathasivam A, Rosenberg HK, Shapiro S, Wang H, Rapaport R. Pelvic ultrasonography in the evaluation of central precocious puberty: comparison with leuprolide stimulation test. J Pediatr. 2011 Sep;159(3):490-5.

17 Mogensen SS, Aksglaede L, Mouritsen A, Sørensen K, Main KM, Gideon P, et al. Pathological and incidental findings on brain MRI in a single-center study of 229 consecutive girls with early or precocious puberty. PLoS One. 2012;7(1):e29829.

18 Lee J, Kim J, Yang A, Cho SY, Jin DK. Etiological trends in male central precocious puberty. Ann Pediatr Endocrinol Metab. 2018 Jun;23(2):75-80.

19 Cantas-Orsdemir S, Garb JL, Allen HF. Prevalence of cranial MRI findings in girls with central precocious puberty: a systematic review and meta-analysis. J Pediatr Endocrinol Metab. 2018 Jul;31(7):701-10.

20 Kaplowitz PB. Do 6-8 year old girls with central precocious puberty need routine brain imaging? Int J Pediatr Endocrinol. 2016; 2016(1):9.

21 Neely EK, Hintz RL, Wilson DM, Lee PA, Gautier T, Argente J, et al. Normal ranges for immunochemiluminometric gonadotropin assays. J Pediatr. 1995 Jul;127(1):40-6.

22 Resende EA, Lara BH, Reis JD, Ferreira BP, Pereira GA, Borges MF. Assessment of basal and gonadotropin-releasing hormone-stimulated gonadotropins by immunochemiluminometric and immunofluorometric assays in normal children. J Clin Endocrinol Metab. 2007 Apr;92(4):1424-9.

23 Pasternak Y, Friger M, Loewenthal N, Haim A, Hershkovitz E. The utility of basal serum LH in prediction of central precocious puberty in girls. Eur J Endocrinol. 2012 Feb;166(2): $295-9$.
24 Houk CP, Kunselman AR, Lee PA. The diagnostic value of a brief $\mathrm{GnRH}$ analogue stimulation test in girls with central precocious puberty: a single 30-minute post-stimulation $\mathrm{LH}$ sample is adequate. J Pediatr Endocrinol Metab. 2008 Dec;21(12):1113-8.

25 Carretto F, Salinas-Vert I, Granada-Yvern ML, Murillo-Vallés M, Gómez-Gómez C, Puig-Domingo M, et al. The usefulness of the leuprolide stimulation test as a diagnostic method of idiopathic central precocious puberty in girls. Horm Metab Res. 2014 Dec; 46(13):959-63.

26 Poomthavorn P, Khlairit P, Mahachoklertwattana P. Subcutaneous gonadotropin-releasing hormone agonist (triptorelin) test for diagnosing precocious puberty. Horm Res. 2009;72(2):114-9.

27 Freire AV, Gryngarten MG, Ballerini MG, Arcari AJ, Escobar ME, Bergadá I, et al. Assessment of Estradiol Response after Depot Triptorelin Administration in Girls with Central Precocious Puberty. Horm Res Paediatr. 2016;85(1):58-64.

28 Conn PM, Crowley WF Jr. Gonadotropin-releasing hormone and its analogs. Annu Rev Med. 1994;45:391-405.

29 Lahlou N, Roger M, Chaussain JL, Feinstein MC, Sultan C, Toublanc JE, et al. Gonadotropin and alpha-subunit secretion during long term pituitary suppression by D-Trp6-luteinizing hormone-releasing hormone microcapsules as treatment of precocious puberty. J Clin Endocrinol Metab. 1987 Nov;65(5):94653.

30 Hirsch HJ, Lahlou N, Gillis D, Strich D, Rosenberg-Hagen B, Chertin B, et al. Free alpha-subunit is the most sensitive marker of gonadotropin recovery after treatment of central precocious puberty with the histrelin implant. J Clin Endocrinol Metab. 2010 Jun; 95(6):2841-4.

31 Lewis KA, Goldyn AK, West KW, Eugster EA. A single histrelin implant is effective for 2 years for treatment of central precocious puberty. J Pediatr. 2013 Oct;163(4):1214-6.

32 Tanaka T, Niimi H, Matsuo N, Fujieda K, Tachibana K, Ohyama K, et al. Results of long-term follow-up after treatment of central precocious puberty with leuprorelin acetate: evaluation of effectiveness of treatment and recovery of gonadal function. The TAP144-SR Japanese Study Group on Central Precocious Puberty. J Clin Endocrinol Metab. 2005 Mar;90(3):1371-6.

33 Carel JC, Lahlou N, Guazzarotti L, JoubertCollin M, Roger M, Colle M, et al.; French Leuprorelin Trial Group. Treatment of central precocious puberty with depot leuprorelin. Eur J Endocrinol. 1995 Jun;132(6):699704.

34 Fuld K, Chi C, Neely EK. A randomized trial of 1- and 3-month depot leuprolide doses in the treatment of central precocious puberty. J Pediatr. 2011;159(6):982-7.
35 Carel JC, Blumberg J, Seymour C, Adamsbaum C, Lahlou N; Triptorelin 3-month CPP Study Group. Three-month sustained-release triptorelin $(11.25 \mathrm{mg})$ in the treatment of central precocious puberty. Eur J Endocrinol. 2006 Jan;154(1):119-24.

36 Klein K, Yang J, Aisenberg J, Wright N, Kaplowitz P, Lahlou N, et al. Efficacy and safety of triptorelin 6-month formulation in patients with central precocious puberty. $\mathrm{Pe}$ diatr Endocrinol Metab. 2016 Nov;29(11): 1241-8.

37 Dineen MK, Tierney DS, Kuzma P, Pentikis HS. An evaluation of the pharmacokinetics and pharmacodynamics of the histrelin implant for the palliative treatment of prostate cancer. J Clin Pharmacol. 2005 Nov;45(11): 1245-9.

38 Mericq V, Lammoglia JJ, Unanue N, Villaroel C, Hernández MI, Avila A, et al. Comparison of three doses of leuprolide acetate in the treatment of central precocious puberty: preliminary results. Clin Endocrinol (Oxf). 2009 Nov;71(5):686-90.

39 Neely EK, Silverman LA, Geffner ME, Danoff TM, Gould E, Thornton PS. Random unstimulated pediatric luteinizing hormone levels are not reliable in the assessment of pubertal suppression during histrelin implant therapy. Int J Pediatr Endocrinol. 2013 Dec;2013(1):20.

40 Lee PA, Klein K, Mauras N, Lev-Vaisler T, Bacher P. 36-month treatment experience of two doses of leuprolide acetate 3-month depot for children with central precocious puberty. J Clin Endocrinol Metab. 2014 Sep; 99(9):3153-9.

41 Biro FM, Galvez MP, Greenspan LC, Succop PA, Vangeepuram N, Pinney SM, et al. Pubertal assessment method and baseline characteristics in a mixed longitudinal study of girls. Pediatrics. 2010 Sep;126(3):e583-90.

42 Ma HM, Du ML, Luo XP, Chen SK, Liu L, Chen RM, et al.; Pubertal Study Group of the Society of Pediatric Endocrinology and Genetic Disease, Chinese Medical Association. Onset of breast and pubic hair development and menses in urban chinese girls. Pediatrics. 2009 Aug; 124(2):e269-77.

43 Bereket A. A Critical Appraisal of the Effect of Gonadotropin-Releasing Hormon Analog Treatment on Adult Height of Girls with Central Precocious Puberty. J Clin Res Pediatr Endocrinol. 2017 Dec;9 Suppl 2:33-48.

44 Comite F, Cassorla F, Barnes KM, Hench KD, Dwyer A, Skerda MC, et al. Luteinizing hormone releasing hormone analogue therapy for central precocious puberty. Long-term effect on somatic growth, bone maturation, and predicted height. JAMA. 1986 May;255(19): 2613-6.

45 Franzini IA, Yamamoto FM, Bolfi F, Antonini SR, Nunes-Nogueira VS. GnRH analog is ineffective in increasing adult height in girls with puberty onset after 7 years of age: a systematic review and meta-analysis. Eur J Endocrinol. 2018;179(6):381-90. 
46 Bar A, Linder B, Sobel EH, Saenger P, DiMartino-Nardi J. Bayley-Pinneau method of height prediction in girls with central precocious puberty: correlation with adult height. J Pediatr. 1995 Jun;126(6):955-8.

47 Jaruratanasirikul S, Thongkum K, Krisaneepaiboon S, Sriplung H. Girls with early puberty attain a near-final height similar to their target height. J Pediatr Endocrinol Metab. 2011;24(5-6):339-45.

48 Allali S, Lemaire P, Couto-Silva AC, Prété G Trivin C, Brauner R. Predicting the adult height of girls with central precocious puberty. Med Sci Monit. 2011 Jun;17(6):PH41-8.

49 Schoelwer MJ, Donahue KL, Didrick P, Eugster EA. One-Year Follow-Up of Girls with Precocious Puberty and Their Mothers: Do Psychological Assessments Change over Time or with Treatment? Horm Res Paediatr. 2017;88(5):347-53.

50 Wojniusz S, Callens N, Sütterlin S, Andersson S, De Schepper J, Gies I, et al. Cognitive, emotional, and psychosocial functioning of girls treated with pharmacological puberty blockage for idiopathic central precocious puberty. Front Psychol. 2016 Jul; 7:1053.

51 Biro FM, Huang B, Crawford PB, Lucky AW, Striegel-Moore R, Barton BA, et al. Pubertal correlates in black and white girls. J Pediatr. 2006 Feb;148(2):234-40.

52 Cabrera SM, Bright GM, Frane JW, Blethen SL, Lee PA. Age of thelarche and menarche in contemporary US females: a cross-sectional analysis. J Pediatr Endocrinol Metab. 2014 Jan;27(1-2):47-51.

53 Lazar L, Padoa A, Phillip M. Growth pattern and final height after cessation of gonadotropin-suppressive therapy in girls with central sexual precocity. J Clin Endocrinol Metab. 2007 Sep;92(9):3483-9.

54 Pasquino AM, Pucarelli I, Accardo F, Demiraj V, Segni M, Di Nardo R. Long-term observation of 87 girls with idiopathic central precocious puberty treated with gonadotropinreleasing hormone analogs: impact on adult height, body mass index, bone mineral content, and reproductive function. J Clin Endocrinol Metab. 2008 Jan;93(1):190-5.

55 Magiakou MA, Manousaki D, Papadaki M, Hadjidakis D, Levidou G, Vakaki M, et al. The efficacy and safety of gonadotropin-releasing hormone analog treatment in childhood and adolescence: a single center, long-term follow-up study. J Clin Endocrinol Metab. 2010 Jan;95(1):109-17.

56 Guaraldi F, Beccuti G, Gori D, Ghizzoni L. MANAGEMENT OF ENDOCRINE DISEASE: long-term outcomes of the treatment of central precocious puberty. Eur J Endocrinol. 2016 Mar;174(3):R79-87.

57 Bertelloni S, Massart F, Einaudi S, Wasniewska M, Miccoli M, Baroncelli GI. Central Precocious Puberty: Adult Height in Girls Treated with Quarterly or Monthly GonadotropinReleasing Hormone Analog Triptorelin. Horm Res Paediatr. 2015;84(6):396-400.
58 Heger S, Partsch CJ, Sippell WG. Long-term outcome after depot gonadotropin-releasing hormone agonist treatment of central precocious puberty: final height, body proportions, body composition, bone mineral density, and reproductive function. J Clin Endocrinol Metab. 1999 Dec;84(12):4583-90.

59 Bertelloni S, Massart F, Miccoli M, Baroncelli GI. Adult height after spontaneous pubertal growth or GnRH analog treatment in girls with early puberty: a meta-analysis. Eur J Pediatr. 2017;176(6):697-704.

60 Kaplowitz PB, Backeljauw PF, Allen DB. Toward More Targeted and Cost-Effective Gonadotropin-Releasing Hormone Analog Treatment in Girls with Central Precocious Puberty. Horm Res Paediatr. 2018;90(1):1-7.

61 Lee PA, Klein K, Mauras N, Neely EK, Bloch CA, Larsen L, et al. Efficacy and safety of leuprolide acetate 3 -month depot 11.25 milligrams or 30 milligrams for the treatment of central precocious puberty. J Clin Endocrinol Metab. 2012 May;97(5):1572-80.

62 Silverman LA, Neely EK, Kletter GB, Lewis K, Chitra S, Terleckyj O, et al. Long-Term Continuous Suppression With Once-Yearly Histrelin Subcutaneous Implants for the Treatment of Central Precocious Puberty: A Final Report of a Phase 3 Multicenter Trial. J Clin Endocrinol Metab. 2015 Jun;100(6):2354-63.

63 Glab E, Wikiera B, Bieniasz J, Barg E. The influence of $\mathrm{GnRH}$ analog therapy on growth in central precocious puberty. Adv Clin Exp Med. 2016;25(1):27-32.

64 Klein KO, Dragnic S, Soliman AM, Bacher P. Predictors of bone maturation, growth rate and adult height in children with central precocious puberty treated with depot leuprolide acetate. J Pediatr Endocrinol Metab. 2018 Jun; 31(6):655-63.

65 Lee PA, Luce M, Bacher P. Monitoring treatment of central precocious puberty using basal luteinizing hormone levels and practical considerations for dosing with a 3-month leuprolide acetate formulation. J Pediatr Endocrinol Metab. 2016 Nov;29(11):1249-57.

66 Demirbilek H, Alikasifoglu A, Gonc NE, Ozon A, Kandemir N. Assessment of gonadotrophin suppression in girls treated with $\mathrm{GnRH}$ analogue for central precocious puberty; validity of single luteinizing hormone measurement after leuprolide acetate injection. Clin Endocrinol (Oxf). 2012 Jan;76(1): 126-30.

67 Brito VN, Latronico AC, Arnhold IJ, Mendonca BB. A single luteinizing hormone determination 2 hours after depot leuprolide is useful for therapy monitoring of gonadotropin-dependent precocious puberty in girls. J Clin Endocrinol Metab. 2004 Sep;89(9): 4338-42.

68 Lucaccioni L, McNeilly J, Mason A, Giacomozzi C, Kyriakou A, Shaikh MG, et al. The measurement of urinary gonadotropins for assessment and management of pubertal disorder. Hormones (Athens). 2016 Jul;15(3): $377-84$.
69 Lewis KA, Eugster EA. Random luteinizing hormone often remains pubertal in children treated with the histrelin implant for central precocious puberty. J Pediatr. 2013 Mar; 162(3):562-5.

70 Brito VN, Latronico AC, Cukier P, Teles MG Silveira LF, Arnhold IJ, et al. Factors determining normal adult height in girls with gonadotropin-dependent precocious puberty treated with depot gonadotropin-releasing hormone analogs. J Clin Endocrinol Metab. $2008 \mathrm{Jul} ; 93(7): 2662-9$.

71 Klein KO, Barnes KM, Jones JV, Feuillan PP, Cutler GB Jr. Increased final height in precocious puberty after long-term treatment with LHRH agonists: the National Institutes of Health experience. J Clin Endocrinol Metab. 2001 Oct;86(10):4711-6

72 Oostdijk W, Rikken B, Schreuder S, Otten B, Odink R, Rouwé C, et al. Final height in central precocious puberty after long term treatment with a slow release GnRH agonist. Arch Dis Child. 1996 Oct;75(4):292-7.

73 Carel JC, Roger M, Ispas S, Tondu F, Lahlou $\mathrm{N}$, Blumberg J, et al. Final height after longterm treatment with triptorelin slow release for central precocious puberty: importance of statural growth after interruption of treatment. French study group of Decapeptyl in Precocious Puberty. J Clin Endocrinol Metab. 1999 Jun;84(6):1973-8.

74 Lazar L, Padoa A, Phillip M. Growth pattern and final height after cessation of gonadotropin-suppressive therapy in girls with central sexual precocity. J Clin Endocrinol Metab. 2007 Sep;92(9):3483-9.

75 Miller BS, Shukla AR. Sterile abscess formation in response to two separate branded long-acting gonadotropin-releasing hormone agonists. Clin Ther. 2010 Sep;32(10): 1749-51.

76 Davis JS, Alkhoury F, Burnweit C. Surgical and anesthetic considerations in histrelin capsule implantation for the treatment of precocious puberty. J Pediatr Surg. 2014 May; 49(5):807-10.

77 Rahhal S, Clarke WL, Kletter GB, Lee PA, Neely EK, Reiter EO, et al. Results of a second year of therapy with the 12-month histrelin implant for the treatment of central precocious puberty. Int J Pediatr Endocrinol. 2009; 2009(1):812517.

78 Akaboshi S, Takeshita K. A case of atypical absence seizures induced by leuprolide acetate. Pediatr Neurol. 2000 Sep;23(3):266-8.

79 Bosco C, Bosnyak Z, Malmberg A, Adolfsson J, Keating NL, Van Hemelrijck M. Quantifying observational evidence for risk of fatal and nonfatal cardiovascular disease following androgen deprivation therapy for prostate cancer: a meta-analysis. Eur Urol. 2015 Sep;68(3): $386-96$. 
80 Levine GN, D'Amico AV, Berger P, Clark PE, Eckel RH, Keating NL, et al.; American Heart Association Council on Clinical Cardiology and Council on Epidemiology and Prevention, the American Cancer Society, and the American Urological Association. Androgendeprivation therapy in prostate cancer and cardiovascular risk: a science advisory from the American Heart Association, American Cancer Society, and American Urological Association: endorsed by the American Society for Radiation Oncology. CA Cancer J Clin. 2010 May-Jun;60(3):194-201.

81 Drew BJ, Ackerman MJ, Funk M, Gibler WB, Kligfield P, Menon V, et al.; American Heart Association Acute Cardiac Care Committee of the Council on Clinical Cardiology, the Council on Cardiovascular Nursing, and the American College of Cardiology Foundation. Prevention of torsade de pointes in hospital settings: a scientific statement from the American Heart Association and the American College of Cardiology Foundation. Circulation. 2010 Mar;121(8):1047-60.

82 Inman M, Hursh BE, Mokashi A, Pinto T, Metzger DL, Cummings EA. Occurrence of slipped capital femoral epiphysis in children undergoing gonadotropin-releasing hormone agonist therapy for the treatment of central precocious puberty. Horm Res Paediatr. 2013;80(1):64-8.

83 Sasagawa Y, Tachibana O, Nakagawa A, Koya $D$, Iizuka $\mathrm{H}$. Pituitary apoplexy following gonadotropin-releasing hormone agonist administration with gonadotropin-secreting pituitary adenoma. J Clin Neurosci. 2015 Mar; 22(3):601-3.

84 Willemsen RH, Elleri D, Williams RM, Ong KK, Dunger DB. Pros and cons of GnRHa treatment for early puberty in girls. Nat Rev Endocrinol. 2014 Jun;10(6):352-63.

85 Sørensen K, Mouritsen A, Aksglaede L, Hagen CP, Mogensen SS, Juul A. Recent secular trends in pubertal timing: implications for evaluation and diagnosis of precocious puberty. Horm Res Paediatr. 2012;77(3):137-45.

86 Stoll BA, Vatten LJ, Kvinnsland S. Does early physical maturity influence breast cancer risk? Acta Oncol. 1994;33(2):171-6.

87 Prentice P, Viner RM. Pubertal timing and adult obesity and cardiometabolic risk in women and men: a systematic review and meta-analysis. Int J Obes (Lond). 2013;37(8):1036-43.

88 Feuillan PP, Jones JV, Barnes K, Oerter-Klein $\mathrm{K}$, Cutler GB Jr. Reproductive axis after discontinuation of gonadotropin-releasing hormone analog treatment of girls with precocious puberty: long term follow-up comparing girls with hypothalamic hamartoma to those with idiopathic precocious puberty. J Clin Endocrinol Metab. 1999 Jan;84(1):44-9.

89 Lazar L, Meyerovitch J, de Vries L, Phillip M, Lebenthal Y. Treated and untreated women with idiopathic precocious puberty: longterm follow-up and reproductive outcome between the third and fifth decades. Clin Endocrinol (Oxf). 2014 Apr;80(4):570-6.
90 Bertelloni S, Baroncelli GI, Ferdeghini M, Menchini-Fabris F, Saggese G. Final height, gonadal function and bone mineral density of adolescent males with central precocious puberty after therapy with gonadotropinreleasing hormone analogues. Eur J Pediatr. 2000 May;159(5):369-74.

91 Chen M, Eugster EA. Central Precocious Puberty: Update on Diagnosis and Treatment. Paediatr Drugs. 2015 Aug;17(4):27381.

92 Fuqua JS. Treatment and outcomes of precocious puberty: an update. J Clin Endocrinol Metab. 2013 Jun;98(6):2198-207.

93 Rosenfield RL. Clinical review: identifying children at risk for polycystic ovary syndrome. J Clin Endocrinol Metab. 2007 Mar; 92(3):787-96.

94 Franceschi R, Gaudino R, Marcolongo A, Gallo MC, Rossi L, Antoniazzi F, et al. Prevalence of polycystic ovary syndrome in young women who had idiopathic central precocious puberty. Fertil Steril. 2010 Mar; 93(4):1185-91.

95 Chiavaroli V, Liberati M, D’Antonio F, Masuccio F, Capanna R, Verrotti A, et al. GNRH analog therapy in girls with early puberty is associated with the achievement of predicted final height but also with increased risk of polycystic ovary syndrome. Eur J Endocrinol. 2010 Jul;163(1):55-62.

96 Kim EY. Long-term effects of gonadotropinreleasing hormone analogs in girls with central precocious puberty. Korean J Pediatr. 2015 Jan;58(1):1-7.

97 Heger S, Müller M, Ranke M, Schwarz HP, Waldhauser F, Partsch CJ, et al. Long-term $\mathrm{GnRH}$ agonist treatment for female central precocious puberty does not impair reproductive function. Mol Cell Endocrinol. 2006 Jul;254-255:217-20.

98 Ding T, Hardiman PJ, Petersen I, Wang FF, Qu F, Baio G. The prevalence of polycystic ovary syndrome in reproductive-aged women of different ethnicity: a systematic review and meta-analysis. Oncotarget. 2017;8(56): 96351-8.

99 Ibáñez L, Oberfield SE, Witchel S, Auchus RJ, Chang RJ, Codner E, et al. An International Consortium Update: Pathophysiology, Diagnosis, and Treatment of Polycystic Ovarian Syndrome in Adolescence. Horm Res Paediatr. 2017;88(6):371-95.

100 Baumann DA, Landolt MA, Wetterwald R, Dubuis JM, Sizonenko PC, Werder EA. Psychological evaluation of young women after medical treatment for central precocious puberty. Horm Res. 2001;56(1-2):45-50.

101 Kim EY, Lee MI. Psychosocial aspects in girls with idiopathic precocious puberty. Psychiatry Investig. 2012 Mar;9(1):25-8.

102 Xhrouet-Heinrichs D, Lagrou K, Heinrichs C, Craen M, Dooms L, Malvaux P, et al. Longitudinal study of behavioral and affective patterns in girls with central precocious puberty during long-acting triptorelin therapy. Acta Paediatr. 1997 Aug;86(8):808-15.
103 Schoelwer MJ, Donahue KL, Bryk K, Didrick P, Berenbaum SA, Eugster EA. Psychological assessment of mothers and their daughters at the time of diagnosis of precocious puberty. Int J Pediatr Endocrinol. 2015; 2015(1):5.

104 Menk TA, Inácio M, Macedo DB, Bessa DS, Latronico AC, Mendonca BB, et al. Assessment of stress levels in girls with central precocious puberty before and during long-acting gonadotropin-releasing hormone agonist treatment: a pilot study. J Pediatr Endocrinol Metab. 2017 May;30(6):657-62.

105 van der Sluis IM, Boot AM, Krenning EP, Drop SL, de Muinck Keizer-Schrama SM. Longitudinal follow-up of bone density and body composition in children with precocious or early puberty before, during and after cessation of GnRH agonist therapy. J Clin Endocrinol Metab. 2002 Feb;87(2):506-12.

106 Paterson WF, McNeill E, Young D, Donaldson MD. Auxological outcome and time to menarche following long-acting goserelin therapy in girls with central precocious or early puberty. Clin Endocrinol (Oxf). 2004 Nov;61(5):626-34.

107 Traggiai C, Perucchin PP, Zerbini K, Gastaldi R, De Biasio P, Lorini R. Outcome after depot gonadotrophin-releasing hormone agonist treatment for central precocious puberty: effects on body mass index and final height. Eur J Endocrinol. 2005 Sep;153(3): 463-4.

108 Wolters B, Lass N, Reinehr T. Treatment with gonadotropin-releasing hormone analogues: different impact on body weight in normal-weight and overweight children. Horm Res Paediatr. 2012;78(5-6):304-11.

109 Arrigo T, De Luca F, Antoniazzi F, Galluzzi F, Segni M, Rosano M, et al. Reduction of baseline body mass index under gonadotropin-suppressive therapy in girls with idiopathic precocious puberty. Eur J Endocrinol. 2004 Apr;150(4):533-7.

110 Palmert MR, Mansfield MJ, Crowley WF Jr, Crigler JF Jr, Crawford JD, Boepple PA. Is obesity an outcome of gonadotropin-releasing hormone agonist administration? Analysis of growth and body composition in 110 patients with central precocious puberty. J Clin Endocrinol Metab. 1999 Dec;84(12): $4480-8$.

111 Boot AM, De Muinck Keizer-Schrama S, Pols HA, Krenning EP, Drop SL. Bone mineral density and body composition before and during treatment with gonadotropinreleasing hormone agonist in children with central precocious and early puberty. J Clin Endocrinol Metab. 1998 Feb;83(2):370-3.

112 Aguiar AL, Couto-Silva AC, Vicente EJ, Freitas IC, Cruz T, Adan L. Weight evolution in girls treated for idiopathic central precocious puberty with GnRH analogues. J Pediatr Endocrinol Metab. 2006 Nov;19(11): 1327-34.

Bangalore Krishna/Fuqua/Rogol/Klein/

Popovic/Houk/Charmandari/Lee 
113 Lazar L, Lebenthal Y, Yackobovitch-Gavan M, Shalitin S, de Vries L, Phillip M, Meyerovitch J. Treated and untreated women with idiopathic precocious puberty: BMI evolution, metabolic outcome, and general health between third and fifth decades. J Clin Endocrinol Metab. 2015;100(4):1445-51.

114 Antoniazzi F, Zamboni G, Bertoldo F, Lauriola $\mathrm{S}$, Tatò $\mathrm{L}$. Bone development during $\mathrm{GH}$ and GnRH analog treatment. Eur J Endocrinol. 2004 Aug;151 Suppl 1:S47-54.

115 Yanovski JA, Rose SR, Municchi G, Pescovitz OH, Hill SC, Cassorla FG, Cutler GB. Treatment with a luteinizing hormone-releasing hormone agonist in adolescents with short stature. N Engl J Med. 2003;348(10): 908-17.

116 Faienza MF, Brunetti G, Acquafredda A, Delvecchio M, Lonero A, Gaeta A, et al. Metabolic Outcomes, Bone Health, and Risk of Polycystic Ovary Syndrome in Girls with Idiopathic Central Precocious Puberty Treated with Gonadotropin-Releasing Hormone Analogues. Horm Res Paediatr. 2017;87(3): $162-9$.

117 Hembree WC, Cohen-Kettenis PT, Gooren L, Hannema SE, Meyer WJ, Murad MH, et al. Endocrine Treatment of Gender-Dysphoric/Gender-Incongruent Persons: An Endocrine Society Clinical Practice Guideline. J Clin Endocrinol Metab. 2017 Nov; 102(11):3869-903.

118 Coleman E, Bockting W, Botzer M, CohenKettenis P, DeCuypere G, Feldman J, et al. Standards of care for the health of transsexual, transgender, and gender-nonconforming people, version 7. Int J Transgenderism. 2012;13(4):165-232.

119 Kreukels BP, Cohen-Kettenis PT. Puberty suppression in gender identity disorder: the Amsterdam experience. Nat Rev Endocrinol. 2011 May;7(8):466-72.

120 de Vries AL, Cohen-Kettenis PT. Clinical management of gender dysphoria in children and adolescents: the Dutch approach. J Homosex. 2012;59(3):301-20.

121 Schagen SE, Cohen-Kettenis PT, Delemarrevan de Waal HA, Hannema SE. Efficacy and Safety of Gonadotropin-Releasing Hormone Agonist Treatment to Suppress $\mathrm{Pu}$ berty in Gender Dysphoric Adolescents. J Sex Med. 2016 Jul;13(7):1125-32.

122 Chew D, Anderson J, Williams K, May T, Pang K. Hormonal Treatment in Young People With Gender Dysphoria: A Systematic Review. Pediatrics. 2018 Apr;141(4):e20173742.

123 Klink D, Caris M, Heijboer A, van Trotsenburg M, Rotteveel J. Bone mass in young adulthood following gonadotropin-releasing hormone analog treatment and cross-sex hormone treatment in adolescents with gender dysphoria. J Clin Endocrinol Metab. 2015 Feb;100(2):E270-5.

124 Ehrensaft D. Gender nonconforming youth: current perspectives. Adolesc Health Med Ther. 2017 May;8:57-67.
125 Thomas BC, Stanhope R, Leiper AD. Gonadotropin releasing hormone analogue and growth hormone therapy in precocious and premature puberty following cranial irradiation for acute lymphoblastic leukaemia. Horm Res. 1993;39(1-2):25-9.

126 Cara JF, Kreiter ML, Rosenfield RL. Height prognosis of children with true precocious puberty and growth hormone deficiency: effect of combination therapy with gonadotropin releasing hormone agonist and growth hormone. J Pediatr. 1992 May; 120(5):709-15.

127 Adan L, Souberbielle JC, Zucker JM, PierreKahn A, Kalifa C, Brauner R. Adult height in 24 patients treated for growth hormone deficiency and early puberty. J Clin Endocrinol Metab. 1997 Jan;82(1):229-33.

128 Kohn B, Julius JR, Blethen SL. Combined use of growth hormone and gonadotropin-releasing hormone analogues: the national cooperative growth study experience. Pediatrics. 1999 Oct;104(4 Pt 2):1014-8.

129 Mauras N, Attie KM, Reiter EO, Saenger P, Baptista J. High dose recombinant human growth hormone (GH) treatment of GH-deficient patients in puberty increases near-final height: a randomized, multicenter trial. Genentech, Inc., Cooperative Study Group. J Clin Endocrinol Metab. 2000;85(10):365360.

130 Mauras N, Gonzalez de Pijem L, Hsiang HY, Desrosiers P, Rapaport R, Schwartz ID, et al. Anastrozole increases predicted adult height of short adolescent males treated with growth hormone: a randomized, placebocontrolled, multicenter trial for one to three years. J Clin Endocrinol Metab. 2008 Mar; 93(3):823-31.

131 Mericq MV, Eggers M, Avila A, Cutler GB Jr, Cassorla F. Near final height in pubertal growth hormone $(\mathrm{GH})$-deficient patients treated with GH alone or in combination with luteinizing hormone-releasing hormone analog: results of a prospective, randomized trial. J Clin Endocrinol Metab. $2000 \mathrm{Feb} ; 85(2): 569-73$

132 Mul D, Wit JM, Oostdijk W, Van den Broeck J; Dutch Advisory Group on Growth Hormone. The effect of pubertal delay by $\mathrm{GnRH}$ agonist in $\mathrm{GH}$-deficient children on final height. J Clin Endocrinol Metab. 2001 Oct; 86(10):4655-6.

133 Bouvattier C, Coste J, Rodrigue D, Teinturier C, Carel JC, Chaussain JL, et al. Lack of effect of GnRH agonists on final height in girls with advanced puberty: a randomized long-term pilot study. J Clin Endocrinol Metab. 1999 Oct;84(10):3575-8.

134 Cassio A, Cacciari E, Balsamo A, Bal M, Tassinari D. Randomised trial of LHRH analogue treatment on final height in girls with onset of puberty aged 7.5-8.5 years. Arch Dis Child. 1999;81(4):329-32.
135 Carel JC, Hay F, Coutant R, Rodrigue D, Chaussain JL. Gonadotropin-releasing hormone agonist treatment of girls with constitutional short stature and normal pubertal development. J Clin Endocrinol Metab. 1996 Sep;81(9):3318-22.

136 Lazar L, Kauli R, Pertzelan A, Phillip M. Gonadotropin-suppressive therapy in girls with early and fast puberty affects the pace of puberty but not total pubertal growth or final height. J Clin Endocrinol Metab. 2002 May; 87(5):2090-4.

137 Khawaja N, Owaineh H, Batieha A, Frahid O, El-Khateeb M, Ajlouni KM. The Effect of Gonadotropin-Releasing Hormone Analogue on Final Adult Height in Children with Idiopathic Short Stature. Med Princ Pract. 2019 Apr.

138 Lanes R, Gunczler P. Final height after combined growth hormone and gonadotrophinreleasing hormone analogue therapy in short healthy children entering into normally timed puberty. Clin Endocrinol (Oxf). 1998 Aug;49(2):197-202.

139 Job JC, Toublanc JE, Landier F. Growth of short normal children in puberty treated for 3 years with growth hormone alone or in association with gonadotropin-releasing hormone agonist. Horm Res. 1994;41(5-6):17784.

140 Mul D, Oostdijk W, Waelkens JJ, Drop SL. Final height after treatment of early puberty in short adopted girls with gonadotrophin releasing hormone agonist with or without growth hormone. Clin Endocrinol (Oxf). 2005 Aug;63(2):185-90.

141 Tuvemo T, Jonsson B, Gustafsson J, Albertsson-Wikland K, Aronson AS, Häger A, et al Final height after combined growth hormone and GnRH analogue treatment in adopted girls with early puberty. Acta Paediatr. 2004 Nov;93(11):1456-62.

142 Pasquino AM, Pucarelli I, Roggini M, Segni M. Adult height in short normal girls treated with gonadotropin-releasing hormone analogs and growth hormone. J Clin Endocrinol Metab. 2000 Feb;85(2):619-22.

143 Benabbad I, Rosilio M, Tauber M, Paris E, Paulsen A, Berggren L, et al.; Phoenix Study Group. Growth hormone in combination with leuprorelin in pubertal children with idiopathic short stature. Endocr Connect. 2018 May;7(5):708-18.

144 Hernández MI, Martínez-Aguayo A, Cavada $G$, Peña $V$, Trejo $L$, Avila $A$, et al. Accelerated early pubertal progression, ovarian morphology, and ovarian function in prospectively followed low birth weight (LBW) girls. J Pediatr Endocrinol Metab. 2013; 26(3-4):223-30.

145 Lazar L, Pollak U, Kalter-Leibovici O, Pertzelan A, Phillip M. Pubertal course of persistently short children born small for gestational age (SGA) compared with idiopathic short children born appropriate for gestational age (AGA). Eur J Endocrinol. 2003 Nov; 149(5):425-32. 
146 Lem AJ, van der Kaay DC, de Ridder MA, Bakker-van Waarde WM, van der Hulst FJ, Mulder JC, Noordam C, Odink RJ, Oostdijk W, Schroor EJ, Sulkers EJ, Westerlaken C, Hokken-Koelega AC. Adult height in short children born SGA treated with growth hormone and gonadotropin releasing hormone analog: results of a randomized, dose-response GH trial. J Clin Endocrinol Metab. 2012;97(11):4096-105.

147 van der Steen M, Lem AJ, van der Kaay DC, Hokken-Koèelega AC. Puberty and Pubertal Growth in GH-treated SGA Children: Effects of 2 Years of GnRHa Versus No GnRHa. J Clin Endocrinol Metab. 2016 May; 101(5):2005-12.

148 Ataya K, Rao LV, Lawrence E, Kimmel R. Luteinizing hormone-releasing hormone agonist inhibits cyclophosphamide-induced ovarian follicular depletion in rhesus monkeys. Biol Reprod. 1995 Feb;52(2):365-72.

149 Hickman LC, Llarena NC, Valentine LN, Liu $\mathrm{X}$, Falcone T. Preservation of gonadal function in women undergoing chemotherapy: a systematic review and meta-analysis of the potential role for gonadotropin-releasing hormone agonists. J Assist Reprod Genet. 2018;35(4):571-81.

150 Munhoz RR, Pereira AA, Sasse AD, Hoff PM, Traina TA, Hudis CA, et al. Gonadotropin-Releasing Hormone Agonists for Ovarian Function Preservation in Premenopausal Women Undergoing Chemotherapy for Early-Stage Breast Cancer: A Systematic Review and Meta-analysis. JAMA Oncol. 2016 Jan;2(1):65-73.

151 Del Mastro L, Ceppi M, Poggio F, Bighin C, Peccatori F, Demeestere I, Levaggi A, Giraudi S, Lambertini M, D'Alonzo A, Canavese
G, Pronzato P, Bruzzi P. Gonadotropin-releasing hormone analogues for the prevention of chemotherapy-induced premature ovarian failure in cancer women: systematic review and meta-analysis of randomized trials. Cancer Treat Rev. 2014;40(5):675-83.

152 Zhang Y, Xiao Z, Wang Y, Luo S, Li X, Li S. Gonadotropin-releasing hormone for preservation of ovarian function during chemotherapy in lymphoma patients of reproductive age: a summary based on 434 patients. PLoS One. 2013 Nov;8(11):e80444.

153 Blumenfeld Z. Preservation of ovarian function and minimizing premature ovarian failure during chemotherapy using gonadotropin-releasing hormone analogs. Womens Health (Lond). 2011 Nov;7(6):635-40.

154 Blumenfeld Z, Patel B, Leiba R, Zuckerman T. Gonadotropin-releasing hormone agonist may minimize premature ovarian failure in young women undergoing autologous stem cell transplantation. Fertil Steril. 2012 Nov;98(5):1266-70.e1.

155 Nitzschke M, Raddatz J, Bohlmann MK, Stute P, Strowitzki T, von Wolff M. GnRH analogs do not protect ovaries from chemotherapy-induced ultrastructural injury in Hodgkin's lymphoma patients. Arch Gynecol Obstet. 2010 Jul;282(1):83-8.

156 Azem F, Samara N, Cohen T, Ben-Yosef D, Almog B, Lessing JB, et al. Assessment of ovarian reserve following ovarian tissue banking and/or GnRH-a co-treatment prior to chemotherapy in patients with Hodgkin's disease. J Assist Reprod Genet. 2008 NovDec;25(11-12):535-8

157 Demeestere I, Brice P, Peccatori FA, Kentos A, Dupuis J, Zachee P, Casasnovas O, Van Den Neste E, Dechene J, De Maertelaer V,
Bron D, Englert Y. No evidence for the benefit of gonadotropin-releasing hormone agonist in preserving ovarian function and fertility in lymphoma survivors treated with chemotherapy: final long-term report of a prospective randomized trial. J Clin Oncol. 2016;34(22):2568-74.

158 Oktay K, Turan V. Failure of Ovarian Suppression With Gonadotropin-Releasing Hormone Analogs to Preserve Fertility: An Assessment Based on the Quality of Evidence. JAMA Oncol. 2016 Jan;2(1):74-5.

159 Moore HC, Unger JM, Phillips KA, Boyle F, Hitre E, Porter D, Francis PA, Goldstein LJ, Gomez HL, Vallejos CS, Partridge AH, Dakhil SR, Garcia AA, Gralow J, Lombard JM, Forbes JF, Martino S, Barlow WE, Fabian CJ, Minasian L, Meyskens FL, Gelber RD, Hortobagyi GN, Albain KS, et al. Goserelin for ovarian protection during breast-cancer adjuvant chemotherapy. N Engl J Med. 2015; 372(10):923-32.

160 Sugishita Y, Suzuki N. Fertility preservation for adolescent and young adult cancer patients in Japan. Obstet Gynecol Sci. 2018 Jul; 61(4):443-52.

161 Chahvar ST, Al-Shawaf T, Tranquilli AL. Pharmacologic ovarian preservation in young women undergoing chemotherapy. Curr Med Chem. 2014;21(2):223-9.

162 Geier DA, Geier MR. A clinical trial of combined anti-androgen and anti-heavy metal therapy in autistic disorders. Neuro Endocrinol Lett. 2006 Dec;27(6):833-8.

163 Coshway L, Broussard J, Acharya K, Fried K, Msall ME, Lantos JD, et al. Medical Therapy for Inappropriate Sexual Behaviors in a Teen With Autism Spectrum Disorder. Pediatrics. 2016 Apr;137(4):e20154366. 